\title{
Neonatal lipopolysaccharide exposure does not diminish the innate immune response to a subsequent lipopolysaccharide challenge in Holstein bull calves
}

\author{
A. L. Benjamin, ${ }^{*}$ F. T. Korkmaz, ${ }^{*}$ T. H. Elsasser,† and D. E. Kerr*1 \\ *Department of Animal and Veterinary Sciences, College of Agriculture and Life Sciences, University of Vermont, Burlington 05405 \\ †Animal Genomics and Improvement Laboratory, USDA, Agricultural Research Service, Beltsville, MD 20705
}

\begin{abstract}
The innate immune response following experimental mastitis is quite variable between individual dairy cattle. An inflammatory response that minimizes collateral damage to the mammary gland while still effectively resolving the infection following pathogen exposure is beneficial to dairy producers. The ability of a lipopolysaccharide (LPS) exposure in early life to generate a low-responding phenotype and thus reduce the inflammatory response to a later-life LPS challenge was investigated in neonatal bull calves. Ten Holstein bull calves were randomly assigned to either an early life LPS (ELL) group $(\mathrm{n}=5)$ or an early life saline (ELS) group $(\mathrm{n}=5)$. At $7 \mathrm{~d}$ of age, calves received either LPS or saline, and at $32 \mathrm{~d}$ of age, all calves were challenged with an intravenous dose of LPS to determine the effect of the early life treatment (LPS or saline) on the immune response generated toward a subsequent LPS challenge. Dermal fibroblast and monocyte-derived macrophage cultures from each calf were established at age 20 and $27 \mathrm{~d}$, respectively, to model sustained effects from the early life LPS exposure on gene expression and protein production of components within the LPS response pathway. The ELL calves had greater levels of plasma IL-6 and tumor necrosis factor- $\alpha$ than the ELS calves following the early life LPS or saline treatments. However, levels of these 2 immune markers were similar between ELL and ELS calves when both groups were subsequently challenged with LPS. A comparison of the in vitro LPS responses of the ELL and ELS calves revealed similar patterns of protein production and gene expression following an LPS challenge of both dermal fibroblast and monocyte-derived macrophage cultures established from the treatment groups. Whereas an early life exposure to LPS did not result in a dampened inflammatory response toward a later LPS challenge in
\end{abstract}

Received December 22, 2015.

Accepted March 14, 2016.

${ }^{1}$ Corresponding author: david.kerr@uvm.edu these neonatal bull calves, the potential that exposure to inflammation or stress in early life or in utero can create an offspring with a low-responding phenotype as an adult is intriguing and has been documented in rodents. Further work is needed to determine if an inflammatory exposure in utero in a dairy animal would result in a low-responding innate immune phenotype.

Key words: early life lipopolysaccharide, inter-animal variation, inflammatory response

\section{INTRODUCTION}

The innate immune system plays a key role in the clearance of pathogens following an infection such as bovine mastitis. This acute, nonspecific response is initiated when conserved pathogen-associated molecular patterns from a diverse number of pathogens are recognized by germ-line encoded receptors known as pattern recognition receptors that are expressed on a variety of cell types. Lipopolysaccharide from the cell wall of gram-negative bacteria, a major causative agent of bovine mastitis, is recognized by the pattern recognition receptor toll-like receptor (TLR) 4. Once LPS is bound by TLR4, an intracellular signaling cascade activates transcription factors such as nuclear factor-kappa B, which promote the transcription of cytokines including IL-1 $\beta$, IL-6, and tumor necrosis factor $\alpha$ (TNF- $\alpha$; Kawai and Akira, 2007). These 3 cytokines play major roles in driving the pro-inflammatory response by promoting febrility, inflammation, and activation of leukocytes to aid in the clearance of the pathogen (Bannerman, 2009). However, an excessive inflammatory response can be detrimental to the host, causing collateral damage to tissues, such as the mammary gland (Schukken et al., 2011), thereby reducing future milk production and profit (Gröhn et al., 2004). The factors that lead to a more robust inflammatory response in some animals and not in others have not been fully elucidated. Even in controlled intra-mammary challenge models of mastitis, inter-animal variation has been observed in cytokine concentrations in milk or blood, milk bacterial 
counts, and severity of clinical symptoms (Schukken et al., 1999; Lee et al., 2006; Simojoki et al., 2009), supporting the belief that host factors play a major role in determining the severity and outcome of mammary infections (Burvenich et al., 2003).

Genetic polymorphisms in components of the host's pathogen recognition pathways could lead to the variable immune responses between animals. Within cattle, several SNP have been identified in genes encoding the toll-like receptors (Novak, 2014) and SNP in these and other genes involved in the inflammatory response have been associated with individual differences in their resistance to mastitis (Thompson-Crispi et al., 2014). Epigenetic modifications of an animal's DNA can also contribute to the observed phenotypic differences in the immune response of individuals. Methylation of DNA, in particular, has been shown to influence transcription of genes (Moore et al., 2013). In human diseases such as periodontitis and rheumatoid arthritis, aberrant methylation within immune response genes has been linked to an increased risk of disease or severity of symptoms (Benakanakere et al., 2015; Kojima et al., 2015). The role that epigenetics may play in modulating the bovine innate immune response is now being investigated (Paibomesai et al., 2013; Green and Kerr, 2014; Chang et al., 2015) and may provide a more complete picture of how genetic and epigenetic factors combine to produce inflammatory responses following bovine mastitis that range from mild to severe.

While pathogen detection by innate immune cells prompts a robust inflammatory response that is essential to resolving the infection, this response must be under tight regulation to prevent excessive inflammation and extensive tissue damage. Some mechanisms can generate a low responding phenotype in an animal, either transiently or long-term, following pathogen exposure. An animal exposed to a low level of LPS can develop a short-term reduction or even an abolished inflammatory response toward a subsequent LPS exposure, thereby exhibiting endotoxin tolerance (Biswas and Lopez-Collazo, 2009). It has been suggested that this tolerized state, generated primarily through macrophages and their reduced production of $\mathrm{TNF}-\alpha$, could be due to a variety of events, including methylation of histone tails, which modify the chromatin structure of anti- and pro-inflammatory genes (El Gazzar et al., 2007), upregulation of anti-inflammatory or inhibitory genes (Fan and Cook, 2004), and micro-RNA regulation of immune response genes (Baltimore et al., 2008). Additionally, abundant evidence indicates that exposure to inflammation or disease in early life can have long-term consequences on the innate immune response of an animal. Several studies completed on rodents have shown that a neonatal LPS exposure can cause a reduction in the cytokine or febrile response following a LPS challenge in the adult rat (Ellis et al., 2005; Spencer et al., 2011). Thus, it would appear that an early life exposure to LPS has the potential to modify the inflammatory response in the adult animal, creating a low-responding phenotype.

In this current study, we investigated if a single exposure to LPS during the neonatal period would modify the in vivo inflammatory response to a subsequent LPS challenge in dairy calves. Additionally, 2 cellular models, dermal fibroblasts (DF) and monocyte-derived macrophages (MDM), were used to explore if early life exposure to LPS would result in sustained epigenetic modifications of the LPS response of these cells, thereby influencing the innate immune response.

\section{MATERIALS AND METHODS}

\section{Experimental Design and Animal Use}

Holstein bull calves that were free of clinical disease and had received $4 \mathrm{~L}$ of pooled colostrum within $1 \mathrm{~h}$ of birth and a second feeding of pooled colostrum $12 \mathrm{~h}$ later were purchased from a collaborating dairy farm. The calves $(\mathrm{n}=10)$ were brought to the University of Vermont Miller Research Farm at $3.3 \pm 0.5 \mathrm{~d}$ of age and given a 4-d acclimation period. Calves were housed in individual plastic calf hutches and had access to a fenced-in outside area of approximately $3 \mathrm{~m} \times$ $3 \mathrm{~m}$. Free choice water and a commercially available calf starter were offered to each calf throughout the trial. Calves were bucket-fed an ad libitum amount of a $23 \%$ protein, $22 \%$ fat milk replacer (OptiMilk Nature's Formula, Arctic Blend; Poulin Grain, Newport, VT) divided between 2 feedings per day throughout the study period. The University of Vermont Institutional Animal Use and Care Committee approved of all experimental procedures before the commencement of this study. Experimental procedures were conducted as shown in Figure 1.

\section{Early Life Treatment}

Calves were randomly divided into 2 groups: early life LPS (ELL) and early life saline (ELS), each consisting of 5 calves. At approximately $7 \mathrm{~d}$ of age, roughly $2 \mathrm{~h}$ after the morning feeding, the early life treatment was administered to each calf. Calves in the ELL group received a jugular injection of $0.5 \mu \mathrm{g}$ of $\mathrm{LPS} / \mathrm{kg}$ of BW isolated from Escherichia coli O111:B4 (Sigma, St. Louis, MO) diluted in saline, whereas the calves in the ELS group received an equal volume of saline. The 
dose of LPS was based on our previous experiments with 14-mo-old heifers (Green et al., 2011). Prior to a single injection of either the LPS solution or saline, the fur along the jugular vein area was clipped and the area was thoroughly cleansed with $70 \%$ ethanol. Rectal temperatures were collected immediately before the injection (h 0) and hourly for $7 \mathrm{~h}$. Blood samples were collected at h 0,2 , and 6 post-LPS infusion with an 18-gauge Vacutainer needle (BD, Franklin Lakes, NJ) and a 10-mL Vacutainer tube containing 158 USP Units of Sodium Heparin (BD). Tubes were inverted several times to ensure adequate mixing of the anti-coagulant and stored on ice for approximately $2 \mathrm{~h}$ before centrifugation at $800 \times g$ for $20 \mathrm{~min}$ at $4^{\circ} \mathrm{C}$. Plasma was then collected and stored at $-20^{\circ} \mathrm{C}$ for future analysis.

\section{LPS Challenge}

Each calf was fitted with a jugular catheter for the LPS challenge to allow for easier administration of the LPS solution and blood sampling. Twenty-four hours before the catheterization, a 50-cm section of polyethylene tubing (I.D. $1.19 \mathrm{~mm}$, O.D. $1.70 \mathrm{~mm}$; Intramedic, BD) was cut per calf and sanitized in a Nolvasan $\mathrm{S}$ solution (Pfizer, New York, NY). On the day of catheterization, each calf was secured in a headlock and the fur was clipped on top of the jugular vein and the area was cleansed with $70 \%$ ethanol. A 12-gauge, 1.5-inch metal hub needle (Hamilton, Reno, NV) was then inserted into the jugular vein, and 20 to $25 \mathrm{~cm}$ of the polyethylene tubing was inserted through the needle. The needle was then removed, an 18-guage Luer stub adapter (Intramedic) attached, and the catheter filled with heparinized saline. The following day, after morning feeding, a single dose of $0.25 \mu \mathrm{g}$ of LPS $/ \mathrm{kg}$ of BW isolated from E. coli O111:B4 (Sigma) was infused into each calf at $0 \mathrm{~h}$. Heparinized blood samples were collected at $-30 \mathrm{~min}$, and then at $1,2,3,5$, and 7 $\mathrm{h}$ postinfusion and stored on ice. Plasma was isolated within $2 \mathrm{~h}$ and stored at $-20^{\circ} \mathrm{C}$ for future analysis.

\section{Plasma IL-6 and TNF- $\alpha$ Quantification}

Concentrations of IL-6 in plasma samples were determined with a commercially available bovine IL-6 ELISA kit (Thermo Scientific, Rockford, IL). The capture and detection antibodies were both plated at 1:100 and the streptavidin-horseradish peroxidase was plated at 1:400. Recombinant bovine IL-6 (Thermo Scientific) was used at the assay standard. Concentrations of TNF- $\alpha$ were determined via RIA as previously described (Elsasser et al., 2005).

\section{Dermal Fibroblast Isolation}

Skin biopsies were collected from the ELL $(\mathrm{n}=5)$ and ELS $(\mathrm{n}=5)$ calves as previously described (Kandasamy et al., 2011). Briefly, DF were isolated following a 6 -h digest with $0.5 \%$ collagenase type I enzyme (Life Technologies, Grand Island, NY). The collagenasedigested tissue was filtered, centrifuged, and the cell pellet was reconstituted with Dulbecco's modified Eagle medium (DMEM; Hyclone Laboratories, Logan, UT) containing 10\% fetal bovine serum (FBS; Hyclone Laboratories), a $1 \times$ antibiotic cocktail $(100 \mathrm{U} / \mathrm{mL}$ of penicillin, $100 \mu \mathrm{g} / \mathrm{mL}$ of streptomycin, and $0.25 \mu \mathrm{g} /$ $\mathrm{mL}$ of amphotericin B; Hyclone Laboratories), and $1 \times$ insulin-transferrin-selenium (ITS; Mediatech, Herndon, VA) and seeded into a $25-\mathrm{cm}^{2}$ flask (Corning Inc., Corning, NY). The medium was replaced after an initial 16-h incubation with fresh DMEM (10\% FBS, $1 \times$ antibiotic cocktail, and $1 \times$ ITS). Once confluency was

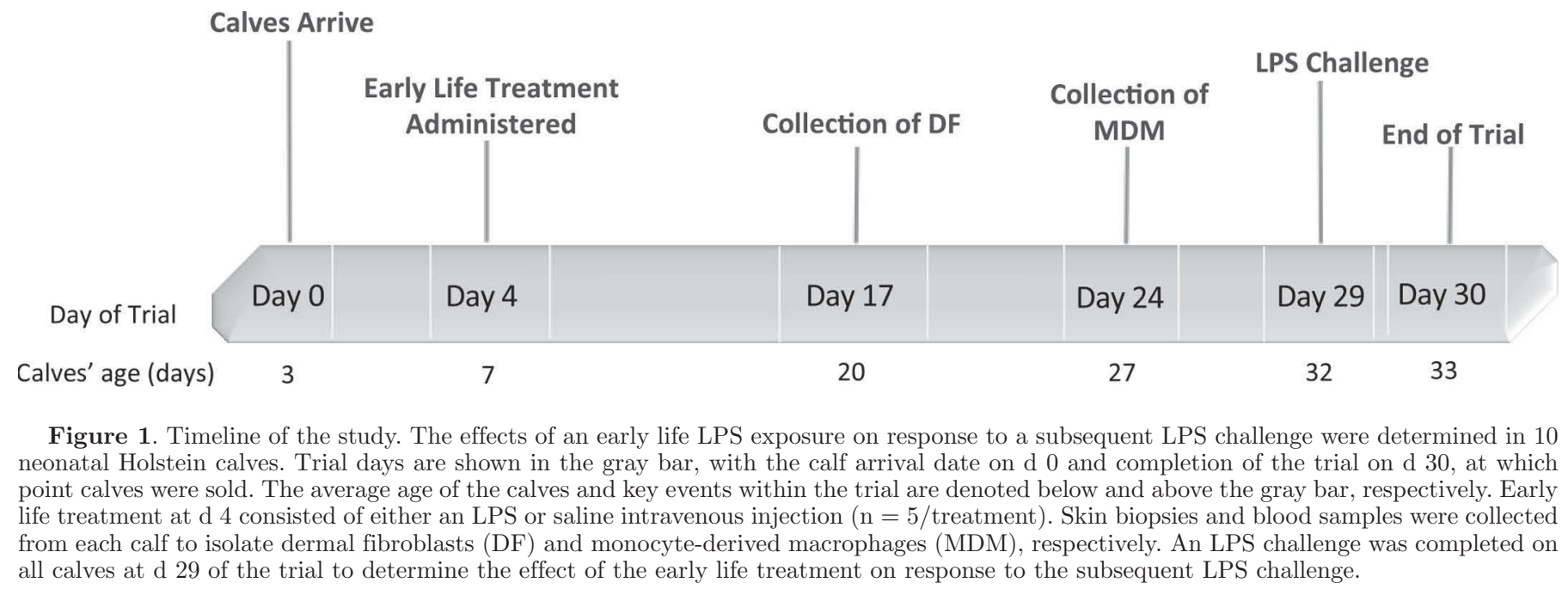


reached, cells were detached with $0.25 \%$ trypsin (MP Biomedical, Santa Ana, CA) and seeded into a $75-\mathrm{cm}^{2}$ flask. After approximately $4 \mathrm{~d}$, cells were expanded into three $75-\mathrm{cm}^{2}$ flasks. Finally, confluent cultures were lifted with trypsin and aliquots of the third passage were diluted in DMEM supplemented with $20 \%$ FBS and 10\% dimethyl sulfoxide (Sigma) and cryopreserved in liquid nitrogen for subsequent challenges.

\section{Monocyte Isolation and Macrophage Culturing}

A 180-mL blood sample was obtained from each of the $\operatorname{ELL}(\mathrm{n}=5)$ and $\operatorname{ELS}(\mathrm{n}=5)$ calves via jugular venipuncture with a $60-\mathrm{mL}$ syringe pretreated with heparin $(10,000$ USP units/mL; Sagent Pharmaceuticals, Schaumburg, IL) and immediately transferred to heparinized vacutainer tubes (BD). Samples were stored on ice for approximately $1 \mathrm{~h}$ before processing. Vacutainer tubes were centrifuged at $800 \times g$ for $20 \mathrm{~min}$ at $4^{\circ} \mathrm{C}$. Peripheral blood mononuclear cells (PBMC) were removed and treated with red blood cell lysis buffer (BioLegend, San Diego, CA). No more than 5 buffy coats were treated with $7.5 \mathrm{~mL}$ of $1 \times$ red blood cell lysis buffer and inverted for $30 \mathrm{~s}$. Two washes were then performed using sterile Dulbecco's PBS (DPBS, Hyclone Laboratories) by centrifuging samples at $500 \times g$ for $5 \mathrm{~min}$ at room temperature. After the second wash, cells were resuspended in $30 \mathrm{~mL}$ of DPBS and $10 \mathrm{~mL}$ of a Percoll (GE Healthcare, Uppsala, Sweden) solution with a specific density of $1.077 \mathrm{~g} / \mathrm{cm}^{3}$ (mixture with 1.5 $M \mathrm{NaCl}$ and $30 \%$ endotoxin-free water) was carefully underlain below the sample. The Percoll gradient was centrifuged at $400 \times g$ for $40 \mathrm{~min}$, at room temperature, with no brake. The PBMC layer was removed from the interface of the DPBS and Percoll and placed into a clean polypropylene tube. One more DPBS wash was performed as stated above to remove residual Percoll. After washing, PBMC were resuspended in $30 \mathrm{~mL}$ of DPBS and centrifuged at $250 \times g$ for $12 \mathrm{~min}$ at room temperature to remove platelets. After the platelet spin, the cells were resuspended in DMEM, 15\% FBS, $1 \times$ ITS, and $1 \times$ penicillin-streptomycin $(100 \mathrm{U} / \mathrm{mL}$ of penicillin and $100 \mu \mathrm{g} / \mathrm{mL}$ of streptomycin). The PBMC were then transferred to a $25-\mathrm{cm}^{2}$ flask and incubated in a humidified chamber at $37^{\circ} \mathrm{C}$ and $5 \% \mathrm{CO}_{2}$ for $3 \mathrm{~h}$. Nonadherent cells were removed and placed in a clean polypropylene tube and adherent cells were washed with DPBS and fresh DMEM medium was added. Nonadherent cells were transferred to a second $25-\mathrm{cm}^{2}$ flask and those that had adhered overnight were washed the next morning and fresh medium was added. Monocytes were incubated for $5 \mathrm{~d}$ and medium was replaced as needed. After $5 \mathrm{~d}$, cells were lifted with $0.25 \%$ trypsin, and the $3 \mathrm{~h}$ cultures and overnight cultures were combined and transferred to a 12-well plate at a concentration of 1.0 $\times 10^{5}$ cells $/ \mathrm{mL}$ in a total volume of $1 \mathrm{~mL}$. The cells were cultured for 3 more days to allow for complete macrophage differentiation.

\section{In Vitro Challenges}

Aliquots of fibroblast cultures isolated from the 10 bull calves were revived in parallel and grown to confluency in a $75-\mathrm{cm}^{2}$ flask. Cells were then detached with trypsin, counted, and seeded into 6-well plates at a concentration of $1.25 \times 10^{5}$ cells $/ \mathrm{mL}$ in $2 \mathrm{~mL}$ total/well. Following a 24-h incubation, cells were exposed to 500 $\mathrm{ng} / \mathrm{mL}$ of ultra-pure LPS isolated from E. coli O111:B4 (Sigma) or fresh culture medium for $24 \mathrm{~h}$. Medium was then collected and centrifuged at 10,000 $\times g$ for $1 \mathrm{~min}$ at room temperature to remove cell debris, and the supernatant was stored at $-20^{\circ} \mathrm{C}$ for future analysis. Cells were lysed at h 0 and 24 post-LPS, and RNA was extracted at stored at $-80^{\circ} \mathrm{C}$ (5 Prime, Gaithersburg, MD) until future analysis.

After $8 \mathrm{~d}$ in culture, macrophages were treated with either medium or medium containing $100 \mathrm{ng} / \mathrm{mL}$ of LPS isolated from $E$. coli O111:B4 for $24 \mathrm{~h}$, after which medium was removed and centrifuged at $10,000 \times g$ for $1 \mathrm{~min}$ at room temperature and supernatant was stored at $-20^{\circ} \mathrm{C}$ until further analysis. Cells were lysed at $\mathrm{h} 0$ and 24 post-LPS, and RNA was extracted at stored at $-80^{\circ} \mathrm{C}$ (5 Prime) until future analysis.

\section{Quantification of In Vitro Immune Response Proteins}

Levels of IL-8 protein produced from fibroblast and MDM cultures following an LPS challenge were determined in duplicate with a commercially available bovine IL-8 ELISA kit (Mabtech, Cincinnati, OH) per the manufacturer's instructions with some modifications. A solution of $1 \mu \mathrm{g} / \mathrm{mL}$ of the monoclonal coating antibody (MT8H6) was plated in $0.05 M$ bicarbonate buffer on a high-affinity 96-well ELISA plate (Corning Life Sciences, Tewksbury, MA) and incubated overnight at $4^{\circ} \mathrm{C}$. Medium samples or recombinant bovine IL- 8 standard (Thermo Scientific) was plated following a series of 3 washes with a solution of DPBS and 0.05\% Tween-20 (DPBS-T; Fisher Bioreagents, Fair Lawn, NJ) and incubated for $2 \mathrm{~h}$ at $20^{\circ} \mathrm{C}$. Plates were washed with DPBS-T and a monoclonal detection antibody (26ESBiotin) was plated at $0.025 \mu \mathrm{g} / \mathrm{mL}$ and incubated for 1 $\mathrm{h}$ at $20^{\circ} \mathrm{C}$. After a series of washes, streptavidin-horseradish peroxidase (Sigma) was plated at $0.1 \mu \mathrm{g} / \mathrm{mL}$ and incubated for $1 \mathrm{~h}$. Lastly, 3,3',5,5'-tetramethylbenzidine substrate (Fisher Scientific, Pittsburgh, PA) was added for approximately $7 \mathrm{~min}$, and the reaction was stopped with $1 \mathrm{M} \mathrm{H}_{2} \mathrm{SO}_{4}$. 
Table 1. Oligonucleotide primers for expression quantification with real-time PCR

\begin{tabular}{|c|c|c|}
\hline Gene name & Primer $\left(5^{\prime}\right.$ to $\left.3^{\prime}\right)$ & Reference \\
\hline Toll-like receptor 4 & ACTGCAGCTTCAACCGTATC & Ibeagha-Awemu et al. (2008) \\
\hline IL-6 & $\begin{array}{l}\text { TGAGGGAAATCAGGAAAATGT } \\
\text { CAGTGTTTGTGGCTGGAGTG }\end{array}$ & Pareek et al. (2005) \\
\hline IL-8 & $\begin{array}{l}\text { GCTGGCTGTTGCTCTCTTG } \\
\text { AGGTGTGGAATGTGTTTTTATG }\end{array}$ & Pareek et al. (2005) \\
\hline Cluster of differentiation 14 & $\begin{array}{l}\text { CTCCAGCACCAAAATGAC } \\
\text { TCCTCTTCCCTCTCTTCC }\end{array}$ & Sohn et al. (2007) \\
\hline IL-1 $\beta$ receptor & $\begin{array}{l}\text { GCTCGTGTCCTCTCATCACA } \\
\text { ACCTTTGTGCTGGTGAATCC }\end{array}$ & Mills et al. (2009) \\
\hline $\mathrm{IL}-1 \beta$ & $\begin{array}{l}\text { CTCTCACAGGAAATGAACCGAG } \\
\text { GCTGCAGGGTGGGCGTATCACC }\end{array}$ & Bougarn et al. (2011) \\
\hline$\beta$-Actin & $\begin{array}{l}\text { GCAAATGCTTCTAGGCGGACT } \\
\text { CAATCTCATCTCGTTTTCTGCG }\end{array}$ & Pareek et al. (2005) \\
\hline
\end{tabular}

${ }^{1}$ The top and bottom sequences are the forward and reverse, respectively.

Concentrations of TNF- $\alpha$ protein in macrophageconditioned medium were determined in duplicate using a custom sandwich ELISA as described above except for the following: coating antibody (polyclonal rabbit anti-bovine TNFo, $1 \mathrm{mg} / \mathrm{mL}$, Thermo Scientific) was diluted 1:200 in 0.05 $M$ bicarbonate buffer, recombinant bovine TNF- $\alpha$ (Kingfisher Biotech Inc., St. Paul, MN) was used as standard, and biotinylated secondary antibody (rabbit anti-bovine TNF- $\alpha$, Thermo Scientific) was diluted 1:1,000 to a concentration of $0.25 \mu \mathrm{g} / \mathrm{mL}$ in DPBS-T. Detection limit of the assay was $156 \mathrm{pg} /$ $\mathrm{mL}$. The concentrations of IL- $1 \beta$ were similarly quantified using a commercially available sandwich ELISA (Thermo Scientific). The detection limit of the assay was $62 \mathrm{pg} / \mathrm{mL}$. All ELISA reactions were quantitated by measuring absorbance at $450 \mathrm{~nm}$ and analyzed by a 4-parameter analysis with optical density corrected against blank wells (Synergy-HT, Bio-Tek, Winooski, VT).

\section{Quantitative Real-Time PCR}

Dermal fibroblasts and MDM were isolated and cultured for an LPS challenge as described above for each of the 10 calves and cell lysate was collected at $\mathrm{h} 0$ and 24 post-LPS for each culture. The PurefectPure RNA Cultured Cell extraction kit (5 Prime), which includes a DNase treatment step to eliminate DNA contamination, was used to extract total RNA from the cell lysate. The RNA concentration was determined using a Qubit Spectrofluorometer (Life Technologies, Carlsbad, CA). The Improm II Reverse Transcriptase Kit (Promega, Madison, WI) was used to complete first strand cDNA synthesis. The following genes were selected for real-time PCR analysis: TLR 4, IL-6, IL-8 (in both $\mathrm{DF}$ and MDM cultures) and $C D 14, I L-1 \beta$ receptor, and $I L-1 \beta$ (in MDM cultures only). Expression levels of these genes were determined by quantitative real-time PCR with a 7500 Fastrun Machine (Applied Biosystems, Carlsbad, CA) using Fermentas Maxima SYBR Green/Fluorescein qPCR Mastermix (Thermo Scientific). An endogenous control gene, $\beta$-actin, was used for normalization of the target genes. Sequences for the constructed primers are listed in Table 1.

\section{Statistical Analysis}

Differences in rectal temperatures, as well as concentrations of plasma TNF- $\alpha$ and IL-6, were determined between the ELL and the ELS calves following the early life treatment and the LPS challenge by a repeated measures ANOVA using Prism 6.0 (GraphPad Software Inc., La Jolla, CA). Differences in immune response proteins and gene expression following an LPS challenge between the fibroblast and MDM cultures collected from the ELL and ELS calves were determined by an unpaired $t$-test in Prism 6.0.

\section{RESULTS}

Blood samples were collected from each calf at 0,2 , and $6 \mathrm{~h}$ following the early life treatment (LPS or saline) to determine concentrations of 2 key inflammatory cytokines, IL-6 and TNF- $\alpha$. Prior to the treatment, levels of IL-6 (Figure 2A) and TNF- $\alpha$ (Figure 2B) were similar between the ELL and ELS calves. However, by h 2 posttreatment levels of IL- 6 and TNF- $\alpha$ in the ELL calves had reached peak values $(P<0.05 ; 14.4 \pm 3.1$ and $3.2 \pm 1.0 \mathrm{ng} / \mathrm{mL}$, respectively), whereas no increase in either cytokine was observed in the ELS calves. At $6 \mathrm{~h}$ posttreatment, IL-6 levels remained elevated $(P$ $<0.05)$ in the ELL calves and plasma TNF- $\alpha$ had decreased to pre-treatment levels, with no detectable changes in plasma IL-6 or TNF- $\alpha$ from the ELS calves. 

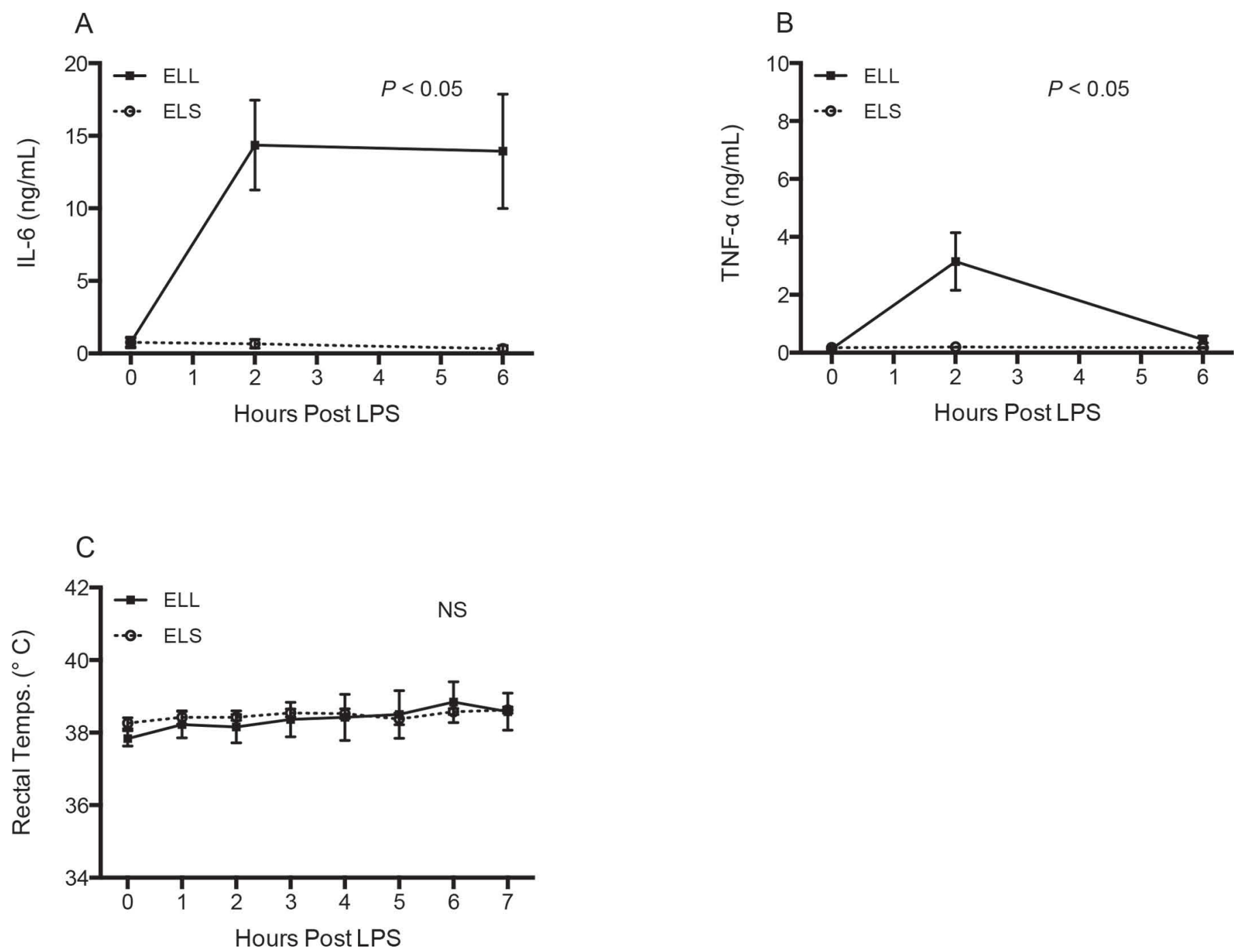

Figure 2. Plasma cytokine responses and rectal temperatures following the early life treatment. Calves were split into 2 groups, one of which received LPS and the other received saline at $7 \mathrm{~d}$ of age. Blood samples were collected from each calf at $\mathrm{h} 0,2$, and 6 following administration of the early life treatment. Plasma levels of IL-6 (A) and tumor necrosis factor- $\alpha$ (TNF- $\alpha$; B) were determined after the early life treatment, and rectal temperatures were taken on animals from both groups $(\mathrm{C})$. ELL = early life LPS; ELS = early life saline. Values are means \pm SEM.

Moderate respiratory distress, and lethargy was typically observed in the ELL animals. Rectal temperatures did not increase due to the early life treatment in either group and were similar between the ELL and the ELS calves (Figure 2C).

Twenty-five days after the early life treatment, an LPS challenge was performed on all 10 calves to compare the LPS response between calves that had received LPS $(\mathrm{n}=5)$ and calves that had received saline $(\mathrm{n}=$ 5 ) in early life. Following an LPS bolus of $0.25 \mu \mathrm{g} / \mathrm{kg}$ of BW, plasma levels of IL-6 increased in both the ELL and ELS calves, reaching similar peak values $(6.7 \pm 0.6$ and $6.1 \pm 0.7 \mathrm{ng} / \mathrm{mL}$ ) at $\mathrm{h} 3$, and decreasing slightly by h 7 postinfusion (Figure 3A). Plasma TNF- $\alpha$ reached maximum concentrations in ELL calves $1 \mathrm{~h}$ following
LPS $(4.8 \pm 1.3 \mathrm{ng} / \mathrm{mL})$, whereas TNF- $\alpha$ concentrations peaked in ELS calves $2 \mathrm{~h}$ post-LPS $(3.9 \pm 1.1 \mathrm{ng} / \mathrm{mL})$. Despite the early temporal differences, $\mathrm{TNF}-\alpha$ levels were similar between ELL and ELS calves for the remainder of the challenge (Figure 3B). Rectal temperatures following the LPS challenge decreased slightly in both groups, as shown in Figure 3C; however, no differences were observed between the ELL and ELS calves.

Skin biopsies were collected from each calf $13 \mathrm{~d}$ after the early life treatment and $12 \mathrm{~d}$ before the LPS challenge to isolate DF. This time point was selected in anticipation that any epigenetic modifications resulting from the ELL treatment that could influence the fibroblast LPS response would be present in our cellular model. Aliquots of fibroblasts from each animal 
were revived and challenged in parallel with LPS (500 $\mathrm{ng} / \mathrm{mL}$ ) for $24 \mathrm{~h}$, and levels of IL-6 and IL-8 protein secreted in medium were used as indicators of that fibroblast culture's LPS response. Fibroblasts isolated from the ELL and ELS calves at approximately $20 \mathrm{~d}$ of age produced similar levels of IL-6 (Figure 4A) and IL-8 (Figure 4C) protein following LPS exposure.

Monocyte-derived macrophages were isolated from each of the calves $(n=10) 21 \mathrm{~d}$ after the early life treatment and $4 \mathrm{~d}$ before the LPS challenge to determine if the in vitro LPS response from the MDM would be dampened due to the ELL treatment. The MDM cultures were challenged with LPS $(100 \mathrm{ng} / \mathrm{mL})$ for 24 h. Concentrations of IL- 6 and IL- 8 protein produced by the MDM cultures following LPS exposure were similar between the treatment groups (Figures $4 \mathrm{~B}$ and $4 \mathrm{D}$ ). Additionally, levels of IL- $1 \beta$ and TNF- $\alpha$ were determined in MDM supernatant following LPS treatment (Figures $4 \mathrm{E}$ and $4 \mathrm{~F}$, respectively). Each of the immune response proteins measured in MDM cultures established from the calves were similar between the 2 early life treatment groups (ELL vs. ELS).

Expression levels of genes involved with the LPS recognition and response pathway were investigated in both the DF and MDM cultures established from all calves. Total RNA was collected from DF and MDM at h 0 and 24 post-LPS and gene message was determined by quantitative real-time PCR. Expression of TLR 4,
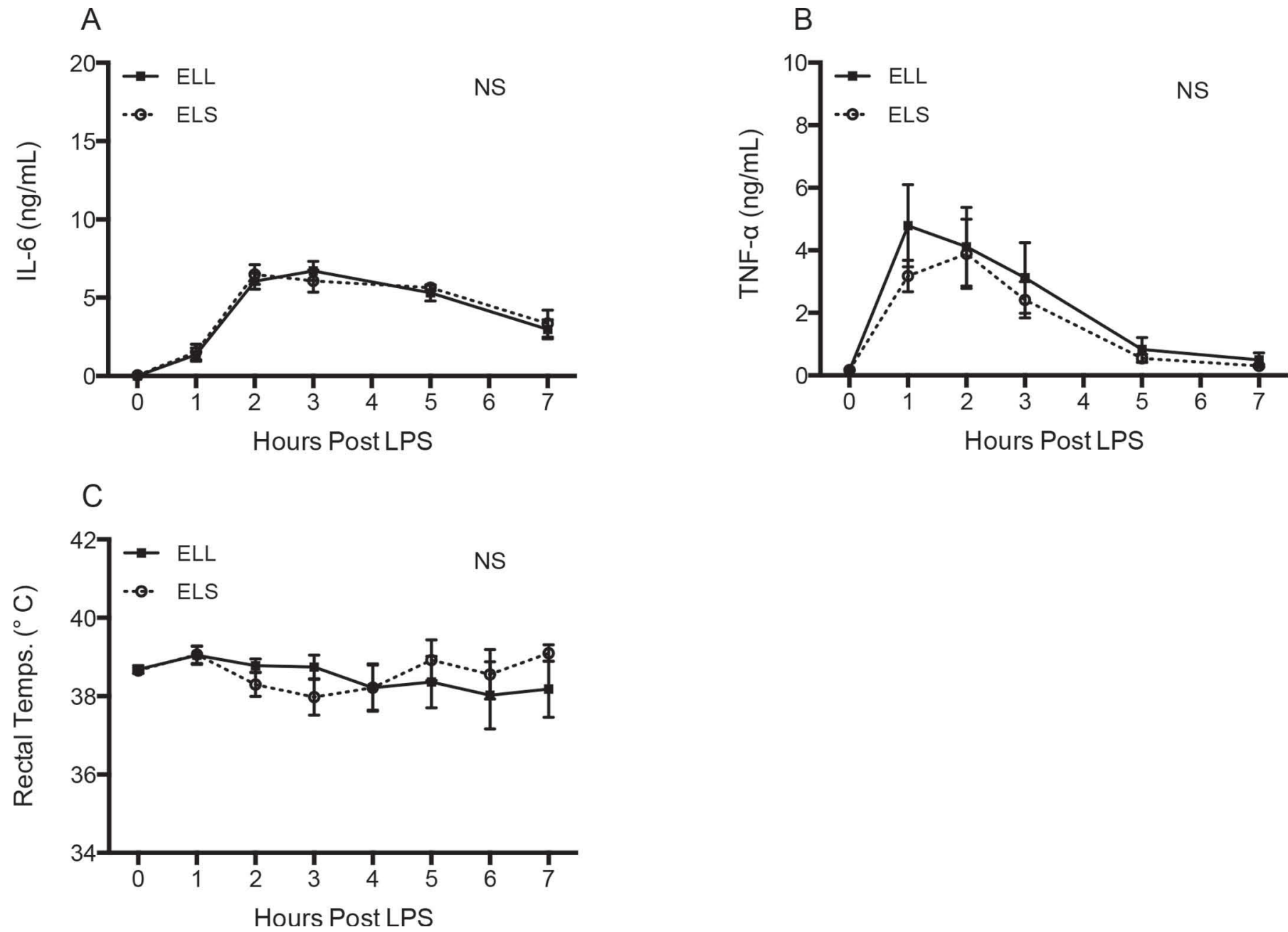

Figure 3. Plasma cytokine response and rectal temperature profiles following an LPS challenge. Holstein bull calves were divided into 2 groups $(\mathrm{n}=5$ /group) based on an early life treatment consisting of either LPS (ELL) or saline (ELS) that was given at $7 \mathrm{~d}$ of age. A subsequent LPS challenge was completed on all calves at $32 \mathrm{~d}$ of age to determine if the early life treatment had an effect on the systemic response to the later LPS. Plasma concentrations of IL-6 (A) and TNF- $\alpha$ (B) were measured in the calves from the ELL and ELS groups following the LPS challenge. Rectal temperatures $\left({ }^{\circ} \mathrm{C}\right)$ of calves following the LPS intravenous infusion at $32 \mathrm{~d}$ of age were not different between the treatment groups. Values are means \pm SEM. 
the receptor responsible for LPS recognition, was consistent following LPS stimulation and was not different between the ELL and ELS groups in either DF or MDM cultures, but was much greater in the MDM cultures (Figures 5A and 5D). The cytokine $I L-6$ and chemokine $I L-8$ are critical immune response genes following LPS exposure, and the expression of these genes increased from h 0 to 24 in both cellular models (Figures $5 \mathrm{~B}$ and $5 \mathrm{E})$. However, no differences were observed between the ELL and ELS calves in either cellular model, although the expression of both IL-6 and IL-8 was much greater in the MDM cultures. Levels of expression of 3 other genes $(C D 14, I L-1 \beta$ receptor, and $I L-1 \beta)$ were determined in control and LPS-treated MDM cultures from the ELL and ELS calves (Figure 5G, H, and I). The expression of $I L-1 \beta$ was markedly induced by LPS treatment of the MDM cultures, whereas the expression of CD14 and the $I L-1 \beta$ receptor were not affected. However, no differences were found in gene expression between the cultures established from the ELL and ELS calves.
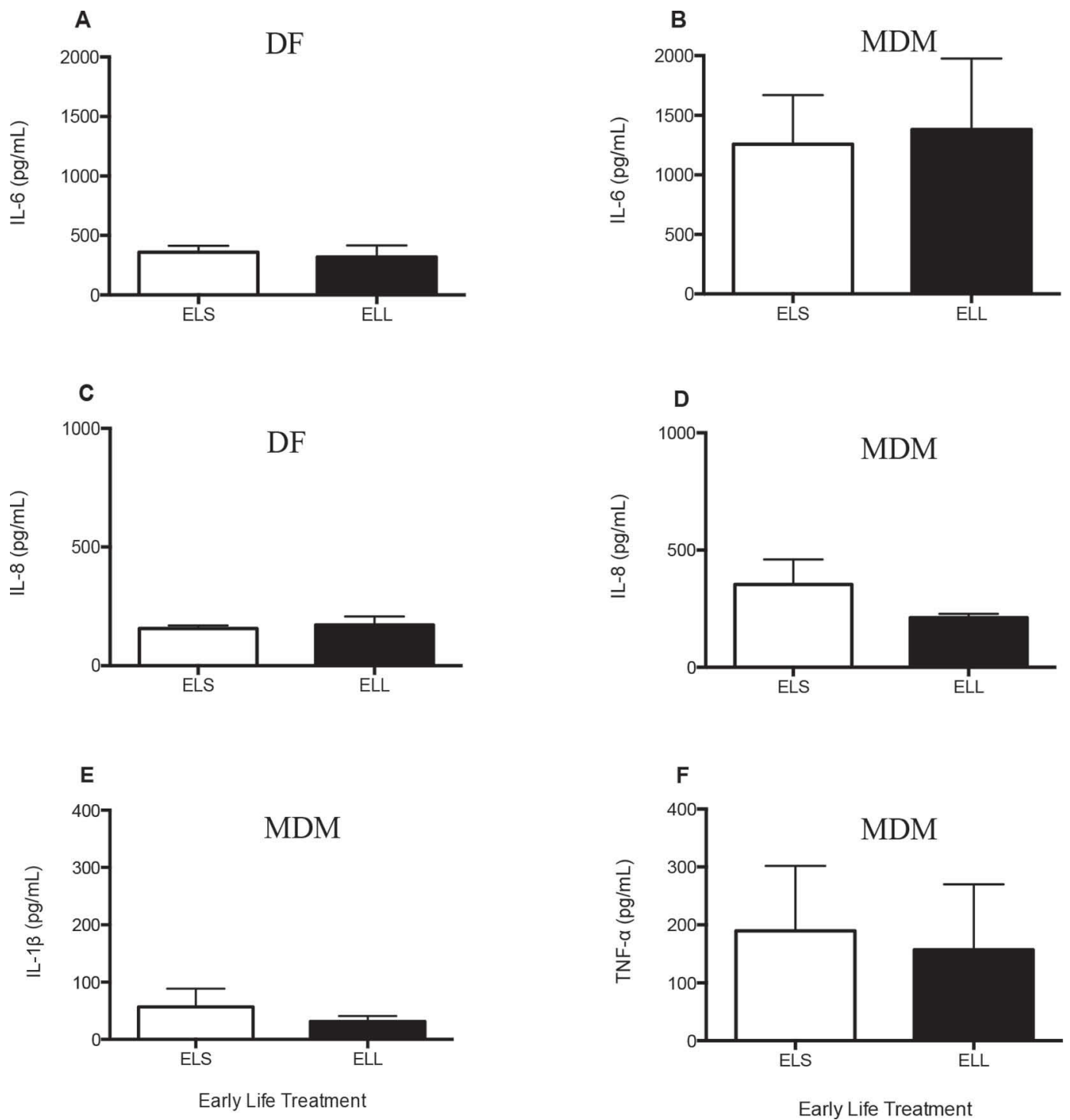

Figure 4. Effect of early life LPS on cellular response to LPS in vitro. Dermal fibroblasts (DF) and monocyte-derived macrophages (MDM) were isolated from each calf $(\mathrm{n}=10)$ to determine if an in vivo LPS exposure during early life would influence the response of these cell types to an in vitro LPS challenge. A 24-h LPS challenge was completed on each cell type; however, DF were treated with $500 \mathrm{ng} / \mathrm{mL}$ of LPS and MDM were treated with $100 \mathrm{ng} / \mathrm{mL}$ of LPS. The amount of secreted IL-6 from DF (A) and MDM (B), IL-8 from DF (C) and MDM (D) following LPS exposure was determined via an ELISA. Panels (E) and (F) represent the levels of IL-1 $\beta$ and TNF- $\alpha$ secreted by MDM post-LPS (concentrations of IL-1 $\beta$ and TNF- $\alpha$ were undetectable in LPS-treated fibroblast cultures). ELL = early life LPS; ELS = early life saline. No significant differences were found between treatment groups. Values are mean \pm SEM. 

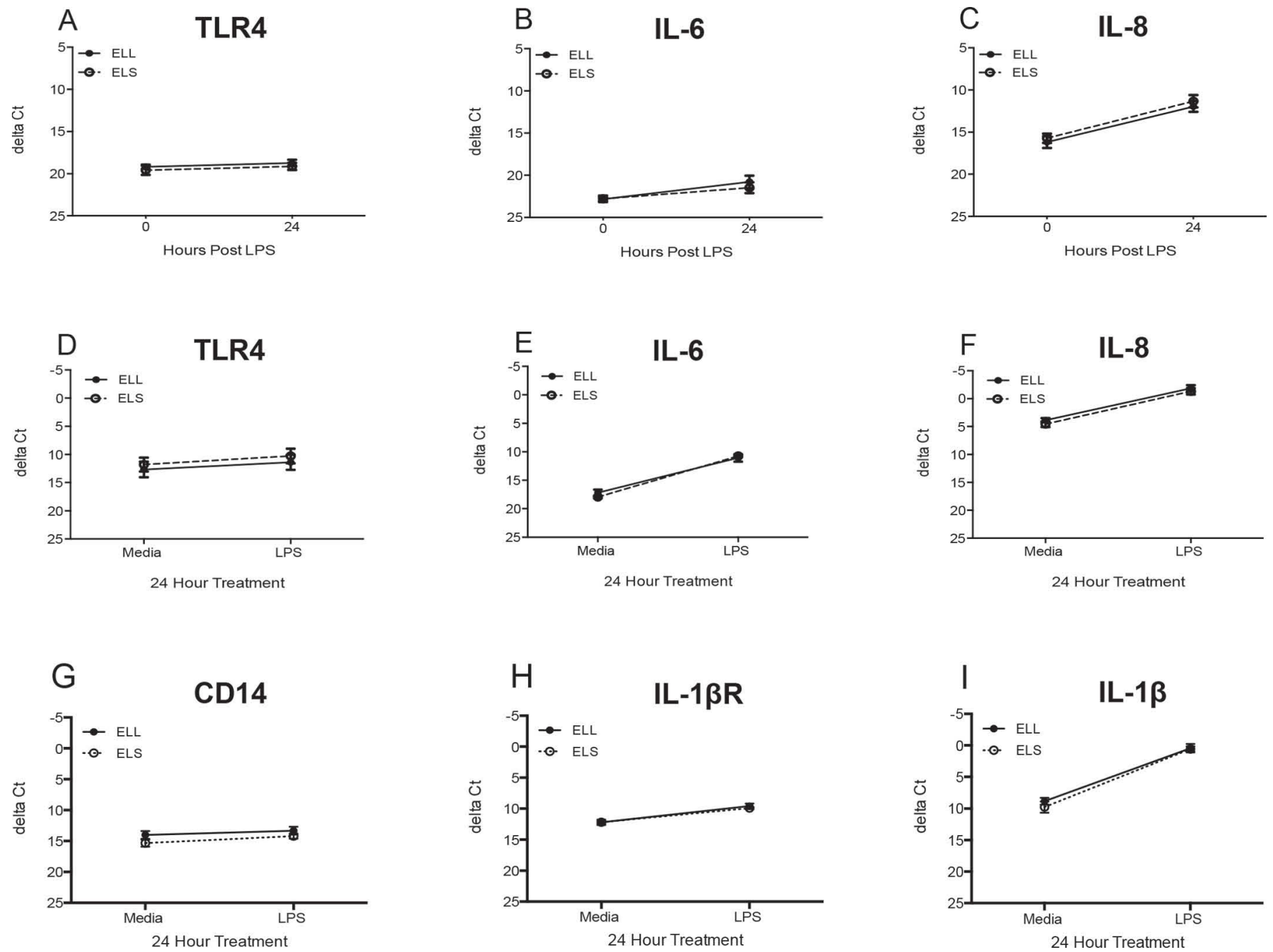

Figure 5. Expression levels (delta cycle threshold, Ct) of LPS recognition and response genes. Dermal fibroblasts (DF) from each calf were revived and challenged with $500 \mathrm{ng} / \mathrm{mL}$ of LPS for $24 \mathrm{~h}$ and total RNA was collected at $\mathrm{h} 0$ and 24 . A similar challenge was completed on monocyte-derived macrophages (MDM) isolated from each calf; however, an LPS dose of $100 \mathrm{ng} / \mathrm{mL}$ was used. Gene expression levels of toll-like receptor (TLR) 4, IL-6, and IL-8 post-LPS were investigated on both DF and MDM cultures using quantitative real-time PCR. Expression levels from DF cultures are presented in panels (A) TLR4, (B) IL-6, and (C) IL-8, and expression levels of MDM cultures are in panels (D) TLR4, (E)

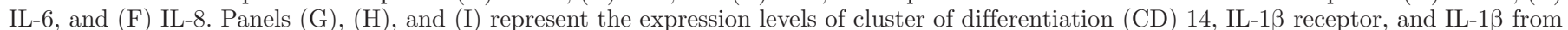
MDM, respectively. Expression values for these 3 genes were not determined in DF cultures. ELL = early life LPS; ELS = early life saline. No significant differences were found between treatment groups. Values are mean \pm SEM.

\section{DISCUSSION}

Previous work from our laboratory and others has shown that dairy cattle manifest a wide range of immune responses following experimentally induced $E$. coli (Kornalijnslijper et al., 2003; Bannerman et al., 2004; Kandasamy et al., 2011) or Staphylococcus aureus (Schukken et al., 1999; Bannerman et al., 2004; Benjamin et al., 2015) mastitis. Some animals exhibit a much more robust inflammatory response during mastitis, characterized by high levels of IL-8, IL-6, and TNF- $\alpha$, which can lead to severe clinical symptoms and damage to the mammary tissue. Inter-animal variation in the expression of genes within the LPS response pathway, including TLR4, the receptor for LPS, may lead to individual differences in the ability to recognize and respond to gram-negative pathogens (Kandasamy and Kerr, 2012). A genetic component to individual differences is highly likely, but new research suggests that epigenetics may also play a role. For example, we have found that the LPS responsiveness of an animal's fibroblasts changes with age. In side-by-side cultures of cells, recovered from cryopreservation but originally collected from the same animals at different ages, we find a marked 
increase in response to LPS stimulation. Furthermore, the age-dependent difference in LPS response of these cells can be abolished by treatment with epigenetic modifiers (Green and Kerr, 2014). Expanding on the inter-animal variation observed in the fibroblast model, cultures established from dairy and beef animals displayed contrasting responses following an in vitro LPS exposure. Whole transcriptome analysis of LPS-treated cultures revealed large breed-dependent differences in the expression of many LPS-responsive genes, including TLR 4, IL-8, TNF- $\alpha, C C L 5$, and CCL2O (Benjamin et al., 2016). These genes, which are associated with the inflammatory response to LPS, were expressed between 2.5- and 7.0-fold higher in Holstein fibroblast cultures compared with Angus cultures. Whereas genetics may contribute to the contrasting in vitro LPS responses between these breeds, offspring from each breed experience very different early life environments, which could lead to varying degrees of epigenetic modifications between the dairy and beef breeds, potentially moderating inflammatory gene expression.

\section{Effect of Neonatal Inflammation}

Several studies have shown that inflammation in the neonatal period (shortly after birth) can lead to sustained suppression of the innate immune response to a subsequent inflammatory challenge. Ellis et al. (2005) observed reduced plasma levels of TNF- $\alpha$ and IL-1 $\beta$ as well as a suppressed febrile response following an LPS challenge of adult rats that had been exposed to LPS at $14 \mathrm{~d}$ of age compared with saline-exposed controls. Similarly, adult rats that had previously received a neonatal dose of LPS $(100 \mu \mathrm{g} / \mathrm{kg})$ at 14 or $21 \mathrm{~d}$ of age produced a lower febrile response, compared with neonatal saline controls, during a subsequent LPS (50 $\mu \mathrm{g} / \mathrm{kg}$ ) challenge (Spencer et al., 2006). However, the timing of the neonatal exposure was found to be critical in that LPS treatments given at 7 or $28 \mathrm{~d}$ of age were not effective. Additionally, the suppressive effect is not observed if the adult challenge dose of LPS is increased to a septic dose of $1 \mathrm{mg} / \mathrm{kg}$ (Spencer et al., 2010). In the current study, we hypothesized that an ELL exposure would generate a low-responding phenotype in Holstein calves toward a subsequent LPS challenge. Surprisingly, ELL calves mounted a similar inflammatory response as the ELS calves during the later LPS challenge that was completed on all calves $25 \mathrm{~d}$ after the first LPS or saline exposure. Plasma levels of TNF- $\alpha$ and IL-6 during the later LPS challenge were comparable between treatment groups, showing the early life treatment with LPS $(0.5 \mu \mathrm{g} / \mathrm{kg})$ at $7 \mathrm{~d}$ of age did not dampen the subsequent inflammatory response to LPS $(0.25 \mu \mathrm{g} / \mathrm{kg})$. The doses used did produce substantial inflammation and may have been too high to generate the expected result.

Although other studies have shown that administering LPS in the neonatal period does reduce the LPS response in the adult, most of these studies have been completed in rats (Spencer et al., 2011; Wang et al., 2011). Different rates of development and maturity within the immune system between calves and rodents may be one explanation for the lack of differences between our LPS- and saline-treated calves. Offspring from species with a comparatively short gestation period, such as rats (length of $21 \mathrm{~d}$ ), are born with a less mature immune system than offspring from species with a longer gestation, cattle for example (length of 9 mo; Holsapple et al., 2003). A less mature immune system during the neonatal period in a rat pup may provide an opportunity for inflammation to epigenetically modify the genes of the immune response in the adult, whereas the immune system of a neonatal calf may be less vulnerable to those types of modifications during that same stage of life. Following parturition, the humoral and cell-mediated immune response of the calf is much lower than an adult cow, but within the first month of life, B-cell numbers increase and the cellmediated response is similar to that of an adult animal (Barrington and Parish, 2001). The immune system in newborn rats is immature and continues to develop during the postnatal period, and although an immune response can be mounted at $21 \mathrm{~d}$ of age, it is not of the same magnitude as an adult animal (Holsapple et al., 2003). A comparison of the degree of immune system development of the rat pups in studies mentioned previously and the calves in this current study suggests the timing of the LPS exposure in the neonatal calves may have been too late to obtain a reduction in the inflammatory response toward an LPS challenge.

\section{Fetal Programming: Maternal Inflammation and Nutrition}

Exposure to bacterial molecules or inflammation while in utero can also alter aspects of an offspring's behavior, health, and development. Increases in anxiety and depression-like behaviors as well as an increased propensity toward developing schizophrenia have been observed in rodents whose dams suffered stress or inflammation during gestation (Ashdown et al., 2006; Depino, 2015). Additionally, several studies have shown that the inflammatory response of the offspring can be suppressed following in utero LPS exposure. For example, Lasala and Zhou (2007) found that an intraperitoneal injection of LPS given to pregnant rats on d 18 of pregnancy greatly reduced the inflammatory response (serum levels of TNF- $\alpha$, IL-1 $1 \beta$, and IL-6) of 
the resulting pups when they were challenged with LPS at $21 \mathrm{~d}$ of age. In a similar study, adult rats that were exposed to LPS in utero at d 16, 18, and 20 of gestation have a blunted inflammatory response toward an LPS challenge as compared with saline-exposed rats (Hodyl et al., 2007). Similarly, offspring of mouse dams that were administered LPS approximately $12 \mathrm{~h}$ after fertilization had a diminished cytokine response following an LPS challenge at $40 \mathrm{wk}$ of age (Williams et al., 2011). Perhaps an in utero exposure of LPS, or maternally derived inflammatory cytokines, would cause a reduction in the inflammatory response toward a later LPS challenge in dairy calves. However, careful consideration of the timing and dosing of the immune stimulant for such a study must be taken, as previous studies conducted in dairy cattle have shown that experimental uterine bacterial infections and LPS infusions can cause abortions before gestational term (Miller et al., 1983; Giri et al., 1990).

\section{LPS Tolerance}

Endotoxin tolerance is a protective mechanism that allows for innate immune cells to experience a transient unresponsive period of time following exposure to low levels of LPS (Biswas and Lopez-Collazo, 2009). Depending on the species, this refractory period can vary in duration, from roughly a week in rats (West and Heagy, 2002), $10 \mathrm{~d}$ in dairy cattle (Petzl et al., 2012), to at least $2 \mathrm{wk}$ in human patients suffering from endotoxemia (Kox et al., 2011). Several studies have shown that a primary result of endotoxin tolerance is a reduction or complete abolishment of TNF- $\alpha$ transcript and protein following a second exposure to LPS (West and Heagy, 2002). Within our study, the calves that were treated with LPS in early life were likely outside the range of a tolerant state during the subsequent LPS challenge that was given $25 \mathrm{~d}$ later. The levels of plasma TNF- $\alpha$ in these calves were actually higher during the later LPS challenge compared with levels reached during the LPS treatment in early life (4 vs. $3 \mathrm{ng} / \mathrm{mL}$, respectively). This demonstrates that the cells primarily responsible for executing LPS tolerance, monocytes and macrophages (Kox et al., 2011), were able to mount an unabated inflammatory response toward the later LPS challenge.

\section{Cellular Models of Innate Immunity}

Extensive use of in vitro models to study the bovine innate immune response is evident, with several different cell types, including mammary epithelial cells (Pareek et al., 2005; Gilbert et al., 2013), neutrophils (Sohn et al., 2007; Revelo and Waldron, 2012), and whole blood (Ballou et al., 2015; Jahan et al., 2015) being used. However, each of these models has drawbacks, including invasive collection procedures, inability to cryopreserve for subsequent challenges, and a heterogeneous cell population. Conversely, MDM do provide a classical innate immune cell model that is relatively easy to collect and culture. Bovine MDM have been shown to be responsive to challenges with Mycobacterium bovis (Magee et al., 2012) and a high dose (1 $\mathrm{gg} /$ $\mathrm{mL}$ ) of LPS (Taraktsoglou et al., 2011), resulting in the induction of many immune-response genes such as $I L-8$, CCL5, and TLR4.

In the current study, the establishment of fibroblast and monocyte cultures from each animal provided 2 cellular models to determine if the ELL induced epigenetic modifications within innate immune response genes that would be reflected in the in vitro LPS response. Additionally, collection of these 2 cell types from each animal allowed for a comparison of the LPS response of 2 cellular models from the same animal. Fibroblasts are long-lived cells that are capable of modulating the inflammatory response as they express innate immune receptors such as TLR and secrete various cytokines and chemokines following pathogen recognition (Buckley et al., 2001; Kandasamy et al., 2011; Benjamin et al., 2015). Alternatively, circulating monocytes are released from bone marrow, and depending on the environmental conditions, undergo apoptosis within a few days or migrate into tissues (Parihar et al., 2010). Once inside the tissue, monocytes will differentiate into macrophages that aid in the clearance of a pathogen or damaged cells (Parihar et al., 2010). These tissueresident macrophages can survive for days to months depending on the needs of the host. Within this study, the main objective in collecting both monocytes and fibroblasts from the saline- and LPS-treated calves was to observe if the ELL created a change, either permanent or temporary, in the in vitro LPS response between the early life treatment groups. Monocytes are continually produced in the bone marrow by myeloid progenitor cells and a systemic cytokine response following LPS exposure may reach these stem cells and induce permanent epigenetic DNA modifications that could be detected in monocytes collected 3 wk later. Dermal fibroblasts, however, are a more stable cell type than monocytes, but may still be susceptible to epigenetic modifications following exposure to a systemic inflammatory response. Although epigenetic modifications could be induced within fibroblast progenitor cells, it is more likely that the fibroblast cells we collected $3 \mathrm{wk}$ postchallenge were the same cells present at the time of the ELL treatment. This may create more transient epigenetic modifications, such as histone modifications, that are still capable of influencing the inflammatory 
response, but are potentially too short-lived to detect the effect after several rounds of cell division while in cell culture. Although progenitor fibroblast cells could be affected, they proliferate at a slower rate and this effect may not be evident only 3 wk after early life treatment. Surprisingly, the in vitro response following an LPS challenge on each of these cell types revealed similar profiles in both cytokine secretion and gene expression between the LPS- and saline-treated calves, which confirmed the lack of differences observed in vivo during the second LPS challenge. Interestingly, the MDM exhibited a much more robust IL-6 response following LPS stimulation as compared with the fibroblasts (Figure 4). Other groups have observed a similar induction of IL-6 in macrophages following LPS stimulation (Jian et al., 1995; Taraktsoglou et al., 2011), but there have been few studies examining differences in the IL-6 response following LPS stimulation between bovine MDM and DF cultures. A comparison between mouse gingival fibroblasts and macrophages revealed that the mouse alveolar macrophage cell line produced less IL-6 following stimulation with LPS compared with the fibroblast cultures (Jones et al., 2010). Although this is inconsistent with our findings, Jones et al. (2010) used a commercially available cell line from mice and challenged with a LPS dose of $1 \mu \mathrm{g} / \mathrm{mL}$ for $24 \mathrm{~h}$. Our MDM model is derived from primary bovine monocytes that are allowed to differentiate into macrophages in culture, and we exposed the cells to a lower LPS dose $(100 \mathrm{ng} / \mathrm{mL})$ for $24 \mathrm{~h}$. Additional challenges that compare the LPS response of primary bovine MDM and DF may be of interest.

\section{CONCLUSIONS}

Variation in the innate immune response toward mammary infections exists in dairy cattle, with some animals exhibiting a mild inflammatory response and others suffering a severe inflammatory reaction that results in collateral damage or death. It has been shown that exposure to inflammation or stress either during early life or in utero can cause epigenetic modifications to the animal's innate immune response. The potential for this type of exposure to create a low-responding phenotype in the offspring, one that mounts an effective inflammatory response without inflicting damage on the host's tissue, is exciting. However, based on the results from this study, an early life exposure to LPS does not cause a dairy calf to mount a milder inflammatory response to a subsequent LPS challenge 25 d later compared with saline-treated control calves. Through the use of MDM and DF, the lack of difference in vivo between LPS-treated and saline-treated calves was confirmed in vitro.

\section{ACKNOWLEDGMENTS}

The authors thank Green Mountain Dairy in Sheldon, Vermont, for providing the calves for this study. Additionally, Matt Bodette and Scott Shumway at the Paul Miller Research Center at the University of Vermont transported the calves to the research farm and aided in the set-up and care of the calves during the trial. Last, many thanks are due to the undergraduate students that helped in feeding and caring for the calves, and collecting samples during the experiment. Funding for this research was supported by a USDAHATCH grant from the Vermont Agricultural Experiment Station (VT-HO1417MS).

\section{REFERENCES}

Ashdown, H., Y. Dumont, M. Ng, S. Poole, P. Boksa, and G. N. Luheshi. 2006. The role of cytokines in mediating effects of prenatal infection on the fetus: Implications for schizophrenia. Mol. Psychiatry 11:47-55.

Ballou, M. A., D. L. Hanson, C. J. Cobb, B. S. Obeidat, M. D. Sellers, A. R. Pepper-Yowell, J. A. Carroll, T. J. Earleywine, and S. D. Lawhon. 2015. Plane of nutrition influences the performance, innate leukocyte responses, and resistance to an oral Salmonella enterica serotype Typhimurium challenge in Jersey calves. J. Dairy Sci. 98:1972-1982.

Baltimore, D., M. P. Boldin, R. M. O'Connell, D. S. Rao, and K. D. Taganov. 2008. MicroRNAs: New regulators of immune cell development and function. Nat. Immunol. 9:839-845.

Bannerman, D. D. 2009. Pathogen-dependent induction of cytokines and other soluble inflammatory mediators during intramammary infection of dairy cows. J. Anim. Sci. 87(Suppl.):10-25.

Bannerman, D. D., M. J. Paape, J. W. Lee, X. Zhao, J. C. Hope, and P. Rainard. 2004. Escherichia coli and Staphylococcus aureus elicit differential innate immune responses following intramammary infection. Clin. Diagn. Lab. Immunol. 11:463-472.

Barrington, G. M., and S. M. Parish. 2001. Bovine neonatal immunology. Vet. Clin. North Am. Food Anim. Pract. 17:463-476.

Benakanakere, M., M. Abdolhosseini, K. Hosur, L. S. Finoti, and D. F. Kinane. 2015. TLR2 promoter hypermethylation creates innate immune dysbiosis. J. Dent. Res. 94:183-191.

Benjamin, A. L., B. B. Green, B. A. Crooker, S. D. McKay, and D. E. Kerr. 2016. Differential responsiveness of Holstein and Angus dermal fibroblasts to LPS challenge occurs without major differences in the methylome. BMC Genomics 17:258.

Benjamin, A. L., B. B. Green, L. R. Hayden, J. W. Barlow, and D. E. Kerr. 2015. Cow-to-cow variation in fibroblast response to a toll-like receptor $2 / 6$ agonist and its relation to mastitis caused by intramammary challenge with Staphylococcus aureus. J. Dairy Sci. 98:1836-1850.

Biswas, S. K., and E. Lopez-Collazo. 2009. Endotoxin tolerance: New mechanisms, molecules and clinical significance. Trends Immunol. 30:475-487.

Bougarn, S., P. Cunha, F. B. Gilbert, A. Harmache, G. Foucras, and P. Rainard. 2011. Staphylococcal-associated molecular patterns enhance expression of immune defense genes induced by IL-17 in mammary epithelial cells. Cytokine 56:749-759.

Buckley, C. D., D. Pilling, J. M. Lord, A. N. Akbar, D. Scheel-Toellner, and M. Salmon. 2001. Fibroblasts regulate the switch from acute resolving to chronic persistent inflammation. Trends Immunol. 22:199-204.

Burvenich, C., V. Van Merris, J. Mehrzad, A. Diez-Fraile, and L. Duchateau. 2003. Severity of E. coli mastitis is mainly determined by cow factors. Vet. Res. 34:521-564. 
Chang, G., W. Petzl, J. Vanselow, J. Gunther, X. Shen, and H. M. Seyfert. 2015. Epigenetic mechanisms contribute to enhanced expression of immune response genes in the liver of cows after experimentally induced Escherichia coli mastitis. Vet. J. 203:339-341.

Depino, A. M. 2015. Early prenatal exposure to LPS results in anxiety- and depression-related behaviors in adulthood. Neuroscience 299:56-65.

El Gazzar, M., B. K. Yoza, J. Y. Hu, S. L. Cousart, and C. E. McCall. 2007. Epigenetic silencing of tumor necrosis factor alpha during endotoxin tolerance. J. Biol. Chem. 282:26857-26864.

Ellis, S., A. Mouihate, and Q. J. Pittman. 2005. Early life immune challenge alters innate immune responses to lipopolysaccharide: Implications for host defense as adults. FASEB J. 19:1519-1521.

Elsasser, T. H., J. W. Blum, and S. Kahl. 2005. Characterization of calves exhibiting a novel inheritable TNF-alpha hyperresponsiveness to endotoxin: Associations with increased pathophysiological complications. J. Appl. Physiol. 98:2045-2055.

Fan, H., and J. A. Cook. 2004. Molecular mechanisms of endotoxin tolerance. J. Endotoxin Res. 10:71-84.

Gilbert, F. B., P. Cunha, K. Jensen, E. J. Glass, G. Foucras, C. Robert-Granie, R. Rupp, and P. Rainard. 2013. Differential response of bovine mammary epithelial cells to Staphylococcus aureus or Escherichia coli agonists of the innate immune system. Vet. Res. 44:40.

Giri, S. N., P. Emau, J. S. Cullor, G. H. Stabenfeldt, M. L. Bruss, R. H. Bondurant, and B. I. Osburn. 1990. Effects of endotoxin infusion on circulating levels of eicosanoids, progesterone, cortisol, glucose and lactic acid, and abortion in pregnant cows. Vet. Microbiol. 21:211-231.

Green, B. B., S. Kandasamy, T. H. Elsasser, and D. E. Kerr. 2011. The use of dermal fibroblasts as a predictive tool of the toll-like receptor 4 response pathway and its development in Holstein heifers. J. Dairy Sci. 94:5502-5514.

Green, B. B., and D. E. Kerr. 2014. Epigenetic contribution to individual variation in response to lipopolysaccharide in bovine dermal fibroblasts. Vet. Immunol. Immunopathol. 157:49-58.

Gröhn, Y. T., D. J. Wilson, R. N. Gonzalez, J. A. Hertl, H. Schulte, G. Bennett, and Y. H. Schukken. 2004. Effect of pathogen-specific clinical mastitis on milk yield in dairy cows. J. Dairy Sci. $87: 3358-3374$

Hodyl, N. A., K. M. Krivanek, E. Lawrence, V. L. Clifton, and D. M. Hodgson. 2007. Prenatal exposure to a pro-inflammatory stimulus causes delays in the development of the innate immune response to LPS in the offspring. J. Neuroimmunol. 190:61-71.

Holsapple, M. P., L. J. West, and K. S. Landreth. 2003. Species comparison of anatomical and functional immune system development. Birth Defects Res. B Dev. Reprod. Toxicol. 68:321-334.

Ibeagha-Awemu, E. M., J. W. Lee, A. E. Ibeagha, D. D. Bannerman, M. J. Paape, and X. Zhao. 2008. Bacterial lipopolysaccharide induces increased expression of toll-like receptor (TLR) 4 and downstream TLR signaling molecules in bovine mammary epithelial cells. Vet. Res. 39:11.

Jahan, N., A. Minuti, and E. Trevisi. 2015. Assessment of immune response in periparturient dairy cows using ex vivo whole blood stimulation assay with lipopolysaccharides and carrageenan skin test. Vet. Immunol. Immunopathol. 165:119-126.

Jian, Z. J., Z. Yang, M. S. Miller, C. D. Carter, D. O. Slauson, and P. N. Bochsler. 1995. Interleukin-6 secretion by bacterial lipopolysaccharide-stimulated bovine alveolar macrophages in vitro. Vet. Immunol. Immunopathol. 49:51-60.

Jones, K. J., S. Ekhlassi, D. Montufar-Solis, J. R. Klein, and J. S. Schaefer. 2010. Differential cytokine patterns in mouse macrophages and gingival fibroblasts after stimulation with porphyromonas gingivalis or Escherichia coli lipopolysaccharide. J. Periodontol. 81:1850-1857.

Kandasamy, S., B. B. Green, A. L. Benjamin, and D. E. Kerr. 2011. Between-cow variation in dermal fibroblast response to lipopolysaccharide reflected in resolution of inflammation during Escherichia coli mastitis. J. Dairy Sci. 94:5963-5975.

Kandasamy, S., and D. E. Kerr. 2012. Genomic analysis of betweencow variation in dermal fibroblast response to lipopolysaccharide. J. Dairy Sci. 95:3852-3864.
Kawai, T., and S. Akira. 2007. Signaling to NF-kappaB by Toll-like receptors. Trends Mol. Med. 13:460-469.

Kojima, A., T. Kobayashi, S. Ito, A. Murasawa, K. Nakazono, and H. Yoshie. 2015. Tumor necrosis factor-alpha gene promoter methylation in Japanese adults with chronic periodontitis and rheumatoid arthritis. J. Periodontal Res. http://dx.doi.org/10.1111/jre.12314.

Kornalijnslijper, E., B. Beerda, I. Daemen, J. van der Werf, T. van Werven, T. Niewold, V. Rutten, and E. Noordhuizen-Stassen. 2003. The effect of milk production level on host resistance of dairy cows, as assessed by the severity of experimental Escherichia coli mastitis. Vet. Res. 34:721-736.

Kox, M., S. de Kleijn, J. C. Pompe, B. P. Ramakers, M. G. Netea, J. G. van der Hoeven, C. W. Hoedemaekers, and P. Pickkers. 2011. Differential ex vivo and in vivo endotoxin tolerance kinetics following human endotoxemia. Crit. Care Med. 39:1866-1870.

Lasala, N., and H. Zhou. 2007. Effects of maternal exposure to LPS on the inflammatory response in the offspring. J. Neuroimmunol. 189:95-101.

Lee, J. W., D. D. Bannerman, M. J. Paape, M. K. Huang, and X. Zhao. 2006. Characterization of cytokine expression in milk somatic cells during intramammary infections with Escherichia coli or Staphylococcus aureus by real-time PCR. Vet. Res. 37:219-229.

Magee, D. A., M. Taraktsoglou, K. E. Killick, N. C. Nalpas, J. A Browne, S. D. Park, K. M. Conlon, D. J. Lynn, K. Hokamp, S. V. Gordon, E. Gormley, and D. E. MacHugh. 2012. Global gene expression and systems biology analysis of bovine monocyte-derived macrophages in response to in vitro challenge with Mycobacterium bovis. PLoS ONE 7:e32034.

Miller, R. B., S. D. Van Camp, and D. A. Barnum. 1983. The effects of intra-amniotic inoculation of Hemophilus somnus on the bovine fetus and dam. Vet. Pathol. 20:574-583.

Mills, J. A., D. S. Zarlenga, P. L. Habecker, and R. M. Dyer. 2009. Age, segment, and horn disease affect expression of cytokines, growth factors, and receptors in the epidermis and dermis of the bovine claw. J. Dairy Sci. 92:5977-5987.

Moore, L. D., T. Le, and G. Fan. 2013. DNA methylation and its basic function. Neuropsychopharmacology 38:23-38.

Novak, K. 2014. Functional polymorphisms in Toll-like receptor genes for innate immunity in farm animals. Vet. Immunol. Immunopathol. 157:1-11.

Paibomesai, M., B. Hussey, M. Nino-Soto, and B. A. Mallard. 2013. Effects of parturition and dexamethasone on DNA methylation patterns of IFN-gamma and IL-4 promoters in CD4+ T-lymphocytes of Holstein dairy cows. Can. J. Vet. Res. 77:54-62.

Pareek, R., O. Wellnitz, R. Van Dorp, J. Burton, and D. Kerr. 2005. Immunorelevant gene expression in LPS-challenged bovine mammary epithelial cells. J. Appl. Genet. 46:171-177.

Parihar, A., T. D. Eubank, and A. I. Doseff. 2010. Monocytes and macrophages regulate immunity through dynamic networks of survival and cell death. J. Innate Immun. 2:204-215.

Petzl, W., J. Gunther, T. Pfister, C. Sauter-Louis, L. Goetze, S. von Aulock, A. Hafner-Marx, H. J. Schuberth, H. M. Seyfert, and H. Zerbe. 2012. Lipopolysaccharide pretreatment of the udder protects against experimental Escherichia coli mastitis. Innate Immun. 18:467-477.

Revelo, X. S., and M. R. Waldron. 2012. In vitro effects of Escherichia coli lipopolysaccharide on the function and gene expression of neutrophils isolated from the blood of dairy cows. J. Dairy Sci. 95:2422-2441.

Schukken, Y. H., J. Gunther, J. Fitzpatrick, M. C. Fontaine, L. Goetze, O. Holst, J. Leigh, W. Petzl, H. J. Schuberth, A. Sipka, D. G. Smith, R. Quesnell, J. Watts, R. Yancey, H. Zerbe, A. Gurjar, R. N. Zadoks, H. M. Seyfert, and members of the Pfizer mastitis research consortium. 2011. Host-response patterns of intramammary infections in dairy cows. Vet. Immunol. Immunopathol. 144:270-289.

Schukken, Y. H., K. E. Leslie, D. A. Barnum, B. A. Mallard, J. H. Lumsden, P. C. Dick, G. H. Vessie, and M. E. Kehrli. 1999. Experimental Staphylococcus aureus intramammary challenge in late lactation dairy cows: Quarter and cow effects determining the probability of infection. J. Dairy Sci. 82:2393-2401. 
Simojoki, H., T. Orro, S. Taponen, and S. Pyorala. 2009. Host response in bovine mastitis experimentally induced with Staphylococcus chromogenes. Vet. Microbiol. 134:95-99.

Sohn, E. J., M. J. Paape, E. E. Connor, D. D. Bannerman, R. H. Fetterer, and R. R. Peters. 2007. Bacterial lipopolysaccharide stimulates bovine neutrophil production of TNF-alpha, IL-1beta, IL-12 and IFN-gamma. Vet. Res. 38:809-818.

Spencer, S. J., E. Field, and Q. J. Pittman. 2010. Neonatal programming by neuroimmune challenge: Effects on responses and tolerance to septic doses of lipopolysaccharide in adult male and female rats. J. Neuroendocrinol. 22:272-281.

Spencer, S. J., M. A. Galic, and Q. J. Pittman. 2011. Neonatal programming of innate immune function. Am. J. Physiol. Endocrinol. Metab. 300:E11-E18.

Spencer, S. J., S. Martin, A. Mouihate, and Q. J. Pittman. 2006. Early-life immune challenge: Defining a critical window for effects on adult responses to immune challenge. Neuropsychopharmacology 31:1910-1918.

Taraktsoglou, M., U. Szalabska, D. A. Magee, J. A. Browne, T. Sweeney, E. Gormley, and D. E. MacHugh. 2011. Transcriptional pro- filing of immune genes in bovine monocyte-derived macrophages exposed to bacterial antigens. Vet. Immunol. Immunopathol. 140:130-139.

Thompson-Crispi, K., H. Atalla, F. Miglior, and B. A. Mallard. 2014. Bovine mastitis: Frontiers in immunogenetics. Front. Immunol. 5:493.

Wang, Z. W., P. Wang, F. H. Lin, X. L. Li, X. F. Li, K. T. O'Byrne, S. T. Hou, and R. Y. Zheng. 2011. Early-life exposure to lipopolysaccharide reduces the severity of experimental autoimmune encephalomyelitis in adulthood and correlated with increased urine corticosterone and apoptotic CD4+ T cells. Neuroscience 193:283-290.

West, M. A., and W. Heagy. 2002. Endotoxin tolerance: A review. Crit. Care Med. 30(Supp.):S64-S73.

Williams, C. L., J. L. Teeling, V. H. Perry, and T. P. Fleming. 2011. Mouse maternal systemic inflammation at the zygote stage causes blunted cytokine responsiveness in lipopolysaccharide-challenged adult offspring. BMC Biol. 9:49. 